\title{
交感神経幹由来の巨大副咽頭間隙神経鞘腫例
}

\author{
篠原 孝之・湯本 英二・兵頭 政光
}

\section{A Case of Giant Parapharyngeal Neurilemmoma Derived from the Cervical Sympathetic Nerve}

Takayuki Shinohara, Eiji Yumoto and Masamitsu Hyodo

(Ehime University)

\begin{abstract}
This report describes a 20 -year-old female with a giant neurilemmoma of cervical sympathetic nerve origin. The tumor arose in the parapharyngeal space, and extended inferiorly to the submandibular region and medially to the opposite side of the posterior pharyngeal wall. She did not show any symptoms suggesting cranial nerve palsy or Horner's trias. The tumor was completely excised using a submandibular approach and the tumor was found to have originated from the superior ganglion of the sympathetic nerve. Miosis and palpebroptosis appeared postoperatively, which confirmed that the tumor had originated from the cervical sympathetic nerve. Postoperative weakness in the left soft palate improved two weeks after surgery. Recovery has been uneventful without any evidence of cranial nerve deficits 16 months since the surgery.
\end{abstract}

Key words : neurilemmoma, cervical sympathetic nerve, parapharyngeal space, Horner's trias, submandibular approach

\section{はじめに}

神経鞘腫は25～45\%が頭頸部領域に発生するとされて いる比較的多い腫瘍である122).頭頸部領域の中でる副 咽頭間腙は第 9 第 12 の下部脳神経扣よび，交感神経が 縦に貫いていることから，この部位の原発腫瘍の中で神 経鞘腫が発生する頻度は比較的高(3)4)。これらの神経 鞘腫の起源神経は迷走神経が約半数を占めており交感 神経幹由来の腫瘍はまれである。著者らは副咽頭間隙か ら咽頭および頸部に進展した巨大な神経鞘腫で, 術中に 交感神経幹由来であることを確認しえた症例を経験した ので若干の文献的考察を加光報告する.

\section{症例}

症例 : 20歳, 女性.

主訴：咽頭腫瘤.

現病歷 : 平成 5 年 12 月末に咽頭痛を訴市市立宇和島病
院耳鼻咽喉科を受診し，扁桃周囲炎で治療を受けた．初 診時に咽頭の粘膜下腫瘤と左頸部腫瘤を指摘され CT, MRI などの画像検査を受けた．副咽頭間陌から左側頸 部に及ぶ腫瘍が認められ，頸部からの生検で神経鞘腫と 診断された. 精查加療目的で平成 6 年 3 月 23 日当科に入 院した.

既往歷，家族歴：特記すべきことなし．

入院時現症 : 左上頸部下䫇角下方に約 $4 \times 3 \mathrm{~cm}$ の表 面平滑で境界明瞭な弾性硬の腫瘤が触知された。この腫 瘤は皮膚との瘉着はなかったが可動性は不良であった。 咽頭後壁の左半分が中咽頭から下咽頭にかけて膨隆して いたが粘膜表面は正常であった（図 1 ). 左側咽頭絞扼反 射は減弱していたが他の脳神経症状は認められなかった。 またホルネル徵候も認められなかった. 他の耳, 鼻, 喉 頭所見には異常を認めなかった。

検査所見 : 造影 CT で左側副咽頭間隙は法とんど造影 


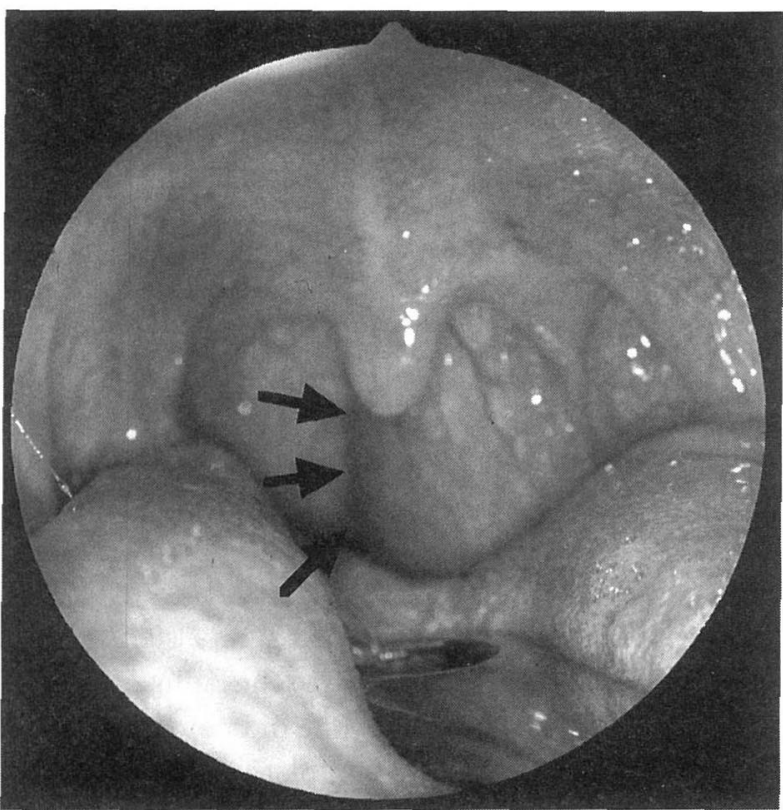

図 1 中咽頭から下咽頭に及ぶ粘膜下腫瘤 矢印は腫瘤が正中を越えて右側に及んでいることを示 す.

効果のない $7 \times 4.7 \times 3 \mathrm{~cm}$ の低吸収域を認めた（図 2 ). 境界は明瞭で内側は正中を越党ていた。内頸静脈は外側 へ強く圧排されて菲薄化して括り, 外頸動脈は前外側へ, 内頸動脈は後方へ圧排されていた。

MRI では中咽頭，下咽頭左側後壁から頸部にかけて $\mathrm{T} 1$ 強調像にて低信号, T2 強調像で著明な高信号を呈 し, Gdで不均一に増強される腫瘍陰影を認めた(図 3 ). 腫瘍の大ささは $8 \times 5 \times 2.5 \mathrm{~cm}$ であった，腫瘍の頭蓋底 への進展は認めなかった。

左頸動脈造影動脈相では左外頸動脈が軽度外側へ圧排 され, 静脈相では土左内頸静脈が外側に強く圧排された所 見が認められた。腫瘍濃染は認められなかった（図 4). 以上の画像診断之前医での頸部生検上り副咽頭間隙から 頸部に広がる神経鞘腫と診断した．起源神経としては舌 咽, 迷走, 副, 舌下神経の各脳神経括よび交感神経が考 えられた。

治療和よび経過：患者が大学生であるため夏休み期間 に手術を行万予定として平成 6 年 4 月 5 日飞一旦退院し た. 平成 6 年 7 月 28 日に再入院し 8 月 2 日に全身麻酔下 に腫瘍摘出術を行った。

皮膚切開は耳下腺手術の S 状切開を甲状軟骨正中部に

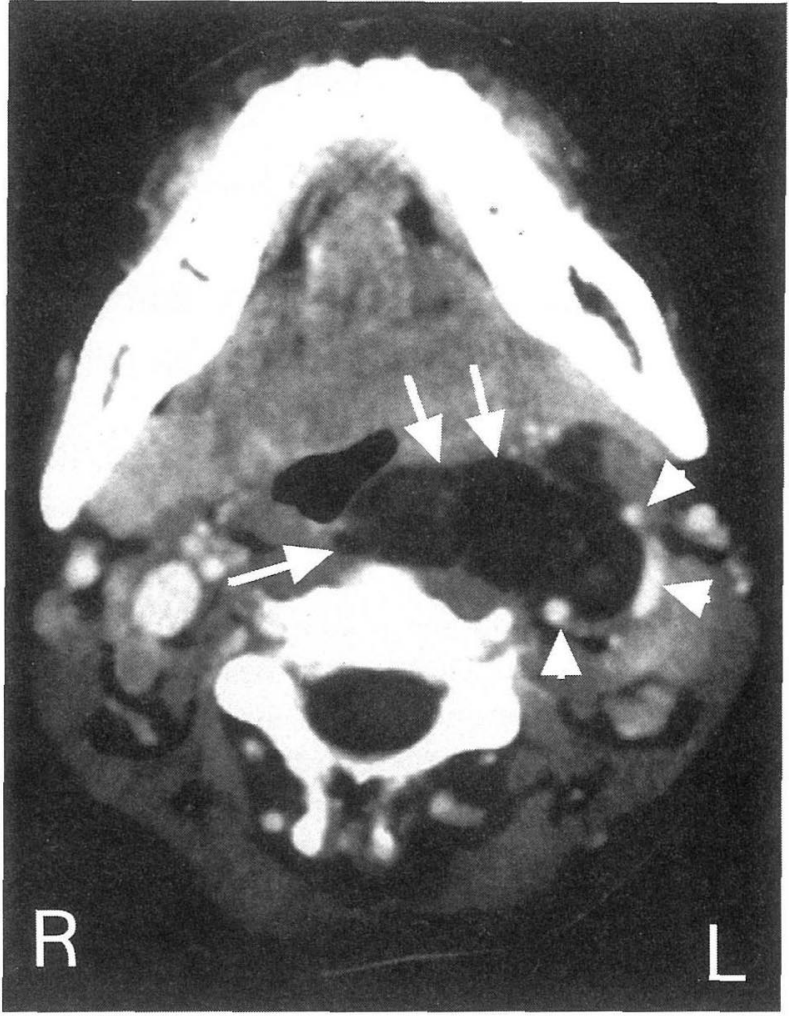

図 2 造影 CT 所見

左側副咽頭間隙飞造影効果のない $7 \times 4.7 \times 3 \mathrm{~cm}$ の低吸 収域を認めた (矢印)。内頸静脈 (矢頭) は外側へ強く圧排 されて菲薄化しており, 外頸動脈( 矢頭) は前外側へ, 内 頸動脈 (矢頭)は後方へ圧排されていた。

まで延長した(図 5 )。左顎下腺を摘出すると柔らかく被 膜に覆われた腫瘍を確認でさた。腫瘍は舌下神経を外側 へ強く圧排し引き延ばしていた．内頸静脈は後方へ著し く圧排され，外頸動脈子後方に圧排され動脈自身は細く なっていた(図 $6 \mathrm{a}$ ). 周囲組織との剥離は可能で中咽頭 後側壁に膨隆していた部分も引き出すことで比較的容易 に一塊として摘出できた。迷走神経は頸動脈鞘内に同定 され，腫瘍との連続性はなかった，腫瘍は交感神経幹の 上頸神経節(矢印) と連続していることが確認でき(図 6 b)，交感神経幹由来と䛦断した。摘出に際し腫瘍をく ぐらせることにより舌下神経を温存した。

術翌日から左眼瞼下垂, 左縮瞳を認めホルネル徴候を 呈し(図 7 ), 軽度の左軟口蓋不全麻痺を認めた。自覚的 にも開鼻声, 鼻腔への水の逆流, 軽度の燕下障害を訴光, 左舌咽神経の不全麻痺々考光られた。術後 2 週間で鼻腔 への逆流は消失し，普通食を摂取できるようになったた 


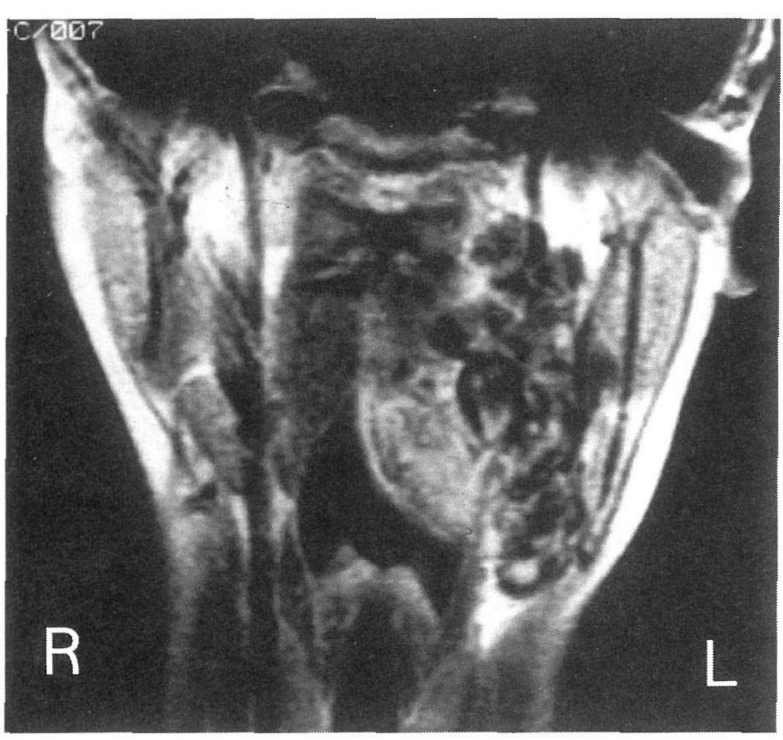

図 3 MRI 所見

前額断で左副咽頭間隙に Gd で不均一に増強される $8 \times 5$ $\times 2.5 \mathrm{~cm}$ の腫瘍陰影を認めた。
め退院した。術後 1 年 4 力月現在，ホルネル徴候には変 化ないが開鼻声，聼下障害は認めず再発もない。

摘出標本：表面は赤褐色平滑で，大ささは $8 \times 5 \times 2.5$ $\mathrm{cm}$ で多数に分葉して抑り実質性の部分之囊胞状の部分 とが混在していた（図８）。病理組織検査では主に Antoni $\mathrm{A}$ 型の組織型を示す神経䩗腫と診断された。

\section{考察}

副咽頭間隙は頭蓋底加ら舌骨上に位置し，逆ピラミッ ド型の構造をしている. その内部は内頸動静脈と舌咽, 迷走, 副, 舌下の各脳神経と交感神経が縱に貫き, 線維 性脂肪組織に満たされている. 副咽頭間隙の上部, 後方 沶よび外側の大部分は骨で境されて持り, 軟部組織とは 内側の咽頭粘膜と外側の下顎骨下部の皮下組織で接して いる.この解剖学的特徴のために腫瘍は柔らかい咽頭, 下顎角部に進展するまで気づかれないことが多い。この 部位の腫瘍は良性腫瘍が $80 \%$ 以上とされて和り6)副咽頭 間隙の原発腫瘍々周团組織からの浸潤腫痬に分けられる。 原発腫瘍の病理組織は神経鞘腫, 多形腺腫, 傍神経節腫 の頻度が高く, 浸潤腫瘍で快耳下腺深葉のダンベル型の

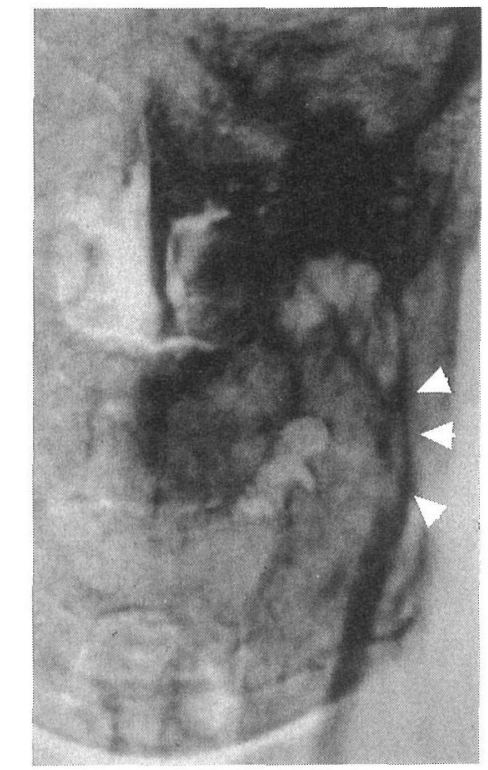

静脈相

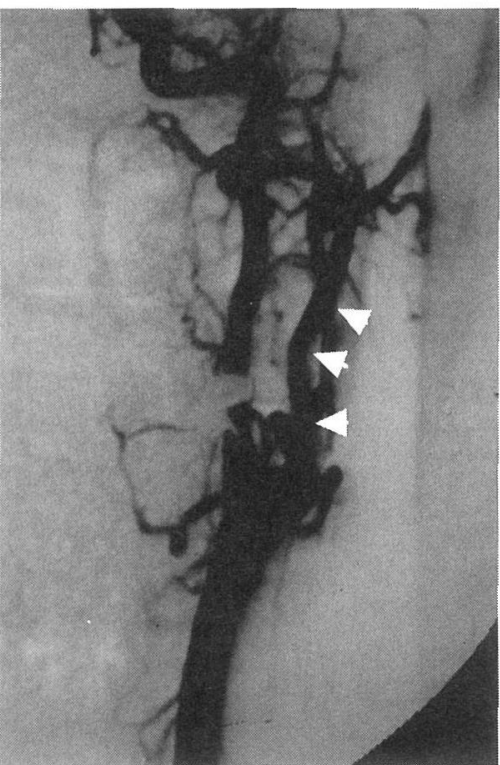

動脈相

図 4 左頸動脈造影所見

明らかな腫瘍濃染は認められなかった。動脈相では左外頸動脈 (矢頭) が軽度外側へ圧排され, 静脈相では左内頸静脈(矢頭)が外側に強く圧 排されていた。 


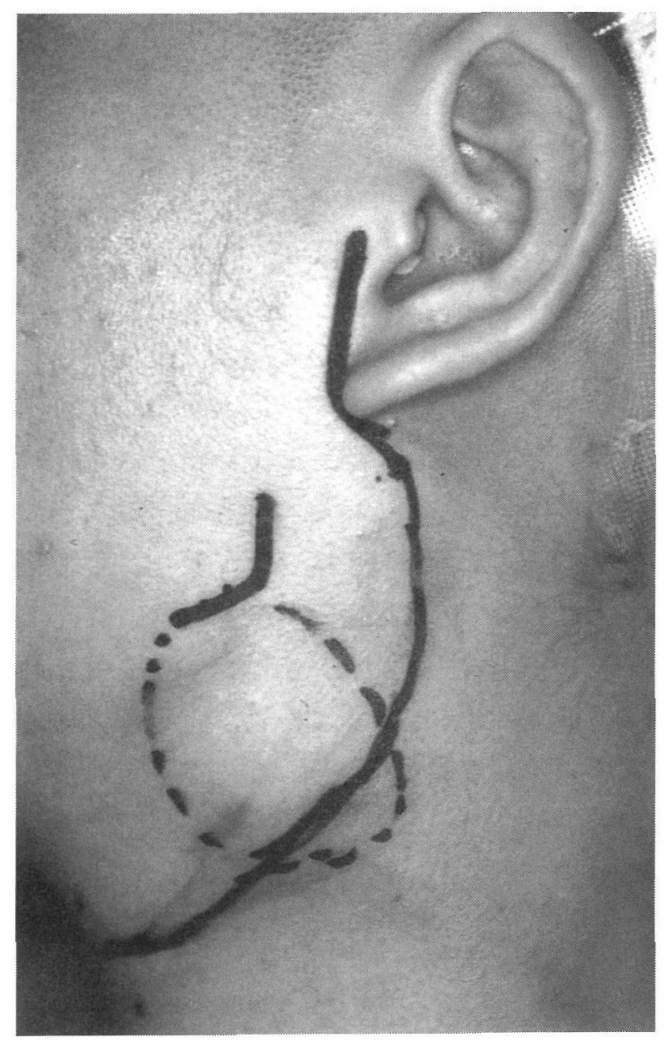

図 5 術前頸部

下顎角下方に約 $4 \times 3 \mathrm{~cm}$ の表面平滑で境界明瞭な弾性硬 の腫瘤を認めた(破線)。皮膚切開は耳下腺手術のS 状切 開を甲状軟骨正中部にまで延長した。前医で行われた生 検による撚痕は切除した。
多形腺腫が大部分を占めている.

神経鞘腫は頭頸部領域に拈ける発生頻度が高く, 全体 の $25 \%{ }^{1)} \sim 45 \%{ }^{3)}$ を占めるとされている. 頸部神経鞘腫 の発生母地は迷走神経が最も多く, ついで腕神経叢と続 いている3）が，交感神経幹由来の神経鞘腫の報告例は多 〈ない7)。臨床症状として迷走神経由来の場合には咳嗽, 片側声帯麻痺による嗄声, 心拍異常など, 頸部交感神経 由来の場合にはホルネル徴候などをきたすとされてい る8)。乙かし実際には症状を伴わず頸部腫瘤や咽頭腫瘤 のみのことが多いため，神経鞘腫の確定診断を下すこと は困難な場合が多い，そのため副咽頭間隙腫瘍の鑑別の ためには画像診断は欠かせない，CT，MRI，血管造影 が重要であるが最近では前 2 者の質的向上があり，血管 造影は限られた症例に施行される傾向にある。耳下腺腫 瘍では腫瘍と耳下腺との間に脂肪層が存在せず，両者の 連続性を認める。神経䩗腫は CT, MRI でともに多形腺 腫に比較して強く造影され, 特に周辺部が造影される hypovascular center が特徵的といわれている。しかし 本症例では腫瘍が大きく囊胞状変化をきたしていたため か，これらの特徵的な造影所見は認められなかった。一 方, 傍神経節腫は上り均一に強く造影される ${ }^{9}$. 血管造 影は血管成分に富んだ腫瘍, 頸動静脈浸潤が疑われる腫 瘍, あるいは頭蓋底へ浸潤した腫瘍で必要となる。

副咽頭間隙へのアプローチには口内法と外切開法があ るが，重要な血管神経の存在を考慮すると外切開法が安 全で確実である。外切開法として顎下部からのアプロー チ，下顎離断によるアプローチ，側頭下窩アプローチ， 経耳下腺アプローチがあるが本症例では術前に神経鞘腫

表 1 本邦に扣ける頸部交感神経鞘腫の大きさと起源神経の同定

\begin{tabular}{|c|c|c|c|c|c|c|c|}
\hline 報告者 & 発表年 & 年齢 & 性 & 患側 & 大きさ $(\mathrm{cm})$ & 術前症状 & $\begin{array}{l}\text { 術中起源経確認 } \\
\text { 视繶 }\end{array}$ \\
\hline 野村10) & 1971 & 25 & 女 & 左 & $6.5 \times 5 \times 4$ & なし & - \\
\hline 山岸ら8) & 1979 & 75 & 女 & 右 & $4.5 \times 3 \times 3$ & ホルネル & - \\
\hline 田頭ら ${ }^{11)}$ & 1981 & 44 & 女 & 左 & $5 \times 4 \times 3$ & なし & - \\
\hline 富沢ら 12) & 1986 & 43 & 女 & 左 & $4 \times 2.5^{*}$ & ホルネル & + \\
\hline 村上 $5^{13)}$ & 1988 & 39 & 男 & 右 & $3.8 \times 3.1 \times 2.7$ & なし & - \\
\hline 馬場ら ${ }^{14)}$ & 1988 & 36 & 女 & 右 & $3.5 \times 3.5^{*}$ & なし & + \\
\hline 竹下 $5^{15)}$ & 1990 & 5 & 男 & 左 & $6 \times 3^{*}$ & なし & + \\
\hline 手塚ら ${ }^{16)}$ & 1991 & 53 & 女 & 左 & $3.6 \times 2 \times 2$ & ホルネル & + \\
\hline 古川ら ${ }^{17)}$ & 1993 & 38 & 女 & 左 & $5.3 \times 4.4 \times 2.3$ & なし & + \\
\hline 伊藤ら ${ }^{18)}$ & 1993 & 26 & 女 & 左 & $5 \times 3.5 \times 2.5$ & なし & + \\
\hline 本症例 & 1997 & 20 & 女 & 左 & $8 \times 5 \times 2.5$ & なし & + \\
\hline
\end{tabular}

*は摘出標本の大きさの記載がなく, 頸部触診での大きさを用いた. 


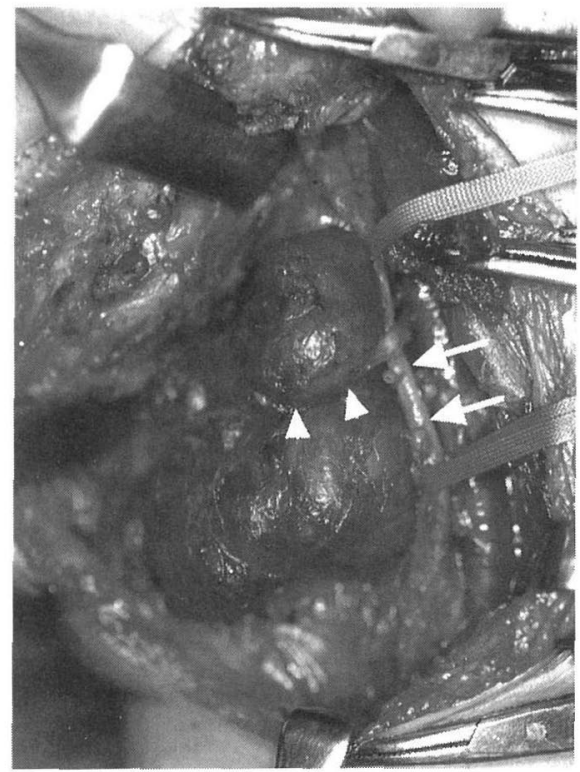

a

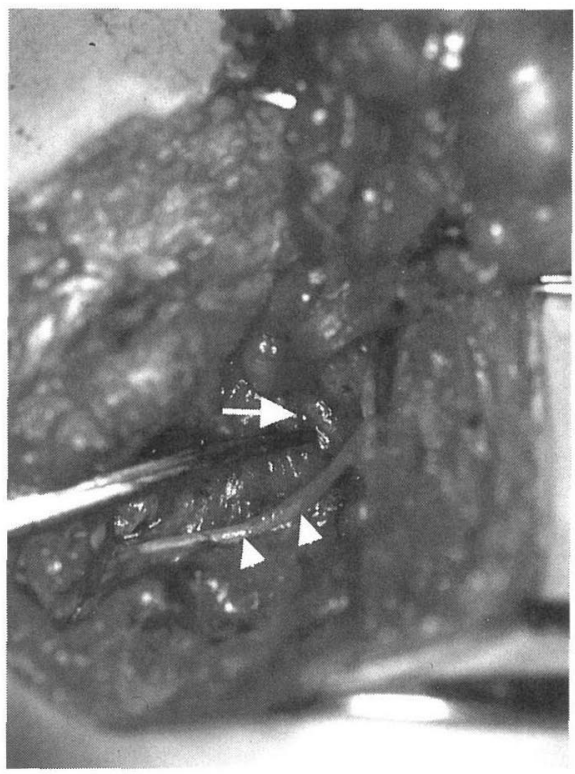

b

図 6 術中所見

a) 腫瘍は被膜飞覆われており, 舌下神経 (矢頭)を外側へ強く压排し引き延ばし ていた. 内頸静脈は後方へ萻しく圧排され, 外頸動脈(矢印) は後方に圧排され, 動脈自身は細くなっていた。

b )止血鈤子の先端で交感神経の上頸神経節を示す (矢印)。腫瘍は上頸神経節と

つながっていることが確認できた，矢頭は舌下神経を示す。

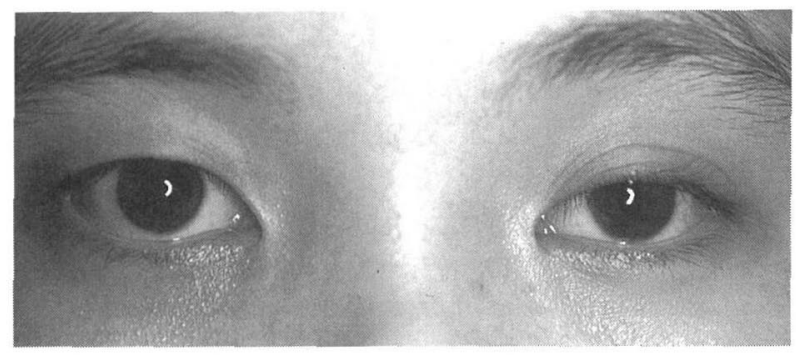

図 7 術後ホルネル徴候 術翌日から左眼瞼下垂, 左縮瞳が認められた。

と診断されていたため周囲組織との剥離は可能と予想し 顎下部アプローチを選択した.

本邦に和ける交感神経䩗腫の大きさ, 術前症状, アプ ローチ法と術後症状について記載のある報告をまとめた

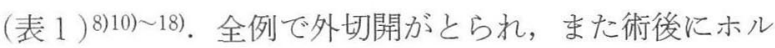
ネル徴候が認められた。 表に大ささ, 術前症状, 術中起 源神経の確認の有無を記載した．起源神経が術中に確認 できたと記載がある報告に“+”，確認していない報告
に“一”を記した。

大きさを名ると，姫とんどが $3 \times 3 \times 3 \mathrm{~cm}$ 以上と大き な腫瘍であるが，本症例が $8 \times 5 \times 2.5 \mathrm{~cm}$ と最も大きい. しかし交感神経由来の神経鞘腫の特徵的症状のホルネル 徵候を術前に示したのは11例中 3 例にすぎず，本症例を 含め, 腫瘍が大きくてもホルネル徵候を示さない例の方 が多いことがわかる、頸部神経鞘腫の起源神経は術後の 神経脱落症状で推察されていたが，最近では摘出を外切 開法で行い，注意深く神経を同定することで起源神経を 確認できる例が増加してきた．本報告でも腫瘍が過去の 報告例中最も大きいにも関わらず，術中に起源神経を確 認でき, 術後もホルネル徵候以外の神経障害を残さず摘 出できた。

$$
\text { まとめ }
$$

副咽頭間隙から側頸部におよぶ巨大な神経鞘腫を経験 した。術前脳神経麻痺やホルネル徵候を認めず, 起源神 経は不明であった。術中所見で上頸神経節との連続性を 確認できたことと術後ホルネル徴候を呈したことから交 感神経幹由来であると診断した。術後軽度の曣下障害を 


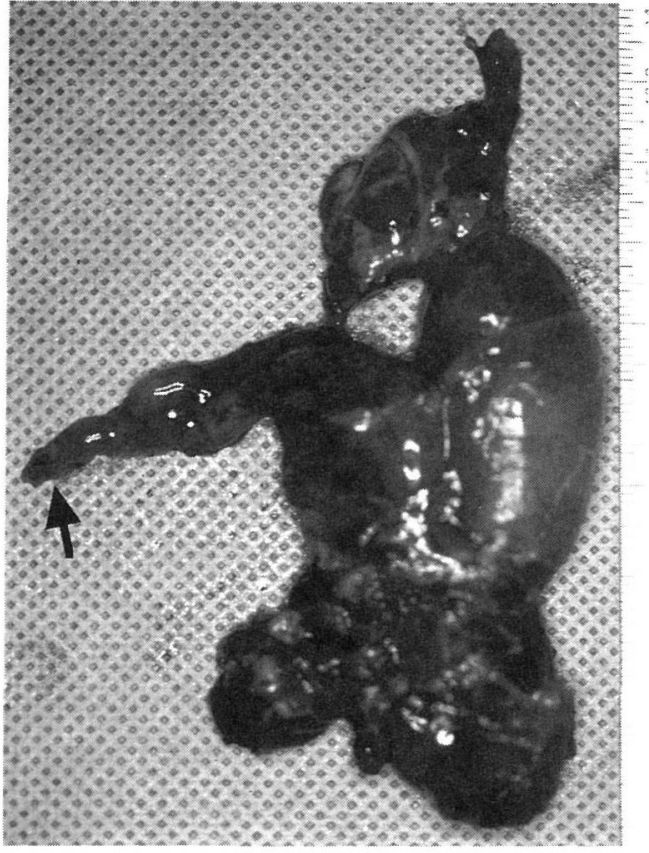

図 8 摘出標本

腫瘍は大きさ $8 \times 5 \times 2.5 \mathrm{~cm}$, 表面は赤褐色平滑で多数 に分葉して括り実質性の部分と襄胞状の部分とが混在し ていた．矢印は上頸神経節につながる部分を示す。

来したが, 経過観察のみで改善した, 他の脳神経脱落症 状は認めなかった。本症例のような巨大腫瘍でも顎下部 経由の慎重な摘出操作により神経脱落症状を最小にとど めて安全に摘出することが可能であった.

\section{参考文献}

1) Conley $J:$ Neurogenous tumors in the neck. Arch Otolaryngol $61: 157 \sim 180,1955$.

2) Putney F: Neurogenic tumors of the head and neck. Laryngoscope $74: 1037 \sim 1059,1964$.

3 ) Gupta TD, Brasfield R and Strong E : Benign solitary schwannomas (neurilemmomas). Cancer $24: 355 \sim 366$, 1969.
4) Work WP and Hybels RL : A study of tumors of the parapharyngeal space. Laryngoscope $84: 1748 \sim 1755$, 1974.

5 ) Maniglia AJ, Chandler JR, Goodwin WJ, et al : Schwannomas of the parapharyngeal space and jugular foramen. Laryngoscope $89:$ 1405 1414, 1979.

6 ) 小田明子, 高橋裕子, 児玉 章 : 副咽頭間隙腫瘍の 1 例 一組織型, 大ささと手術法について一.耳鼻 $38: 236 \sim 240$, 1992.

7 ) 平出文久, 井上憲文, 喜多村健 : 頸部迷走神経ノイリノー 么. 耳喉 $49:$ 209 216, 1977.

8 ) 山岸益夫, 五十嵐秀一, 鈴木昌也: ホルネル症候を示した 頸部交感神経鞘腫. 耳喉 51 : 1075 1078, 1979.

9 ) 高橋光明, 林浩, 金井直樹, 他：副咽頭腔腫瘍の診断 と治療. 耳喉 $59: 617 \sim 623,1987$.

10）野村恭也：咽頭ノイリノーム。耳喉 $43: 371 \sim 378,1971$.

11）田頭宣治, 鈴木 衛, 楠部 滋 : 側頸部に発生したシュワ ノーマ症例. 耳鼻臨床 $74: 2135 \sim 2141,1981$.

12）富沢克夫, 矢島克昭, 黒沢保宏, 他: ホルネル症候を示し た頸部交感神経節由来の神経鞘腫の 1 例. 日耳鼻 $89: 1339$, 1986.

13）村上 泰, 橋口一弘, 泰地秀信, 他 : 頸部腫瘤の鑑別診断 その 2 -Schwannoma一. JOHNS $4:$ 363 369, 1988.

14）馬場洋子, 本田 学, 相川 通, 他: 頸部交感神経より発 生した神経鞘腫の 1 症例. 日耳鼻 $91: 1970,1988$.

15）竹下 元, 上出文博, 滝元 徹, 他: 頸部交感神経由来の 副咽頭神経鞘腫 2 例. 耳鼻 $36: 404 \sim 407,1990$.

16）手塚克彦, 山岨達也, 菅澤 正, 他: 頸部交感神経鞘腫例. 耳鼻臨床 84 : 651 657, 1991.

17）古川政樹, 古川まどか, 大石公直, 他 : 術前診断として超 音波断層法が有用だった頸部交感神経鞘腫の 1 例. 耳喉頭 頸 $65:$ :597 602, 1993.

18）伊藤真人, 嘉藤秀章, 滝元 徹: 頸部交感神経鞘腫を伴っ た両側性聴神経腫瘍. 耳鼻臨床 $86: 15 \sim 18,1993$.

(原稿受付: 平成 9 年 2 月 13 日 原稿採択: 平成 9 年 3 月 19 日 別刷請求先 : 篠原孝之 テ791-02 愛媛県温泉郡重信町大字志津川 